\title{
The significance and perspective of biodiesel production - A European and global view ${ }^{\text {is }}$
}

\author{
Dieter Bockey $^{*}$ \\ Union zur Förderung von Oel- und Proteinpflanzen e.V. (UFOP), Claire-Waldoff-Straße 7, 10117, Berlin, Germany
}

Received 20 August 2019 - Accepted 4 October 2019

\begin{abstract}
Since the nineties, the production of biodiesel has increased considerably worldwide. The motivation for this trend developed very differently with a view to the globally important resource production regions. Biofuels, such as biodiesel, are also playing a role regionally within the context of the growing challenge of a global climate change policy. The contribution is an evaluation of the situation and it demonstrates the limits of the development based on different aspects.
\end{abstract}

Keywords: biodiesel / rapeseed / soybeans / palm oil / quotas / sustainability

\begin{abstract}
Résumé - Importance et perspectives de la production de biodiesel-Un point de vue européen et mondial. Depuis les années 1990, la production de biodiesel a considérablement augmenté dans le monde entier. Les motifs de cette tendance ont évolué très différemment selon les régions de production de ressources d'importance mondiale. Les biocarburants, tels que le biodiesel, jouent également un rôle régional dans le contexte du défi croissant d'une politique mondiale de lutte contre le changement climatique. Cette contribution est une évaluation de la situation et montre les limites du développement en fonction des différents aspects.
\end{abstract}

Mots clés : biodiesel / colza / soya / huile de palme / quotas / durabilité

\section{Introduction}

The development of the global biodiesel production was initially in the nineties motivated exclusively by agricultural market policies. The driver of this development was the reform of the European Union's Common Agricultural Policy (CAP) and as a result the introduction of the obligation to set aside arable land in 1993. In the 15 states that were members of the European Union at the time, up to $10 \%$ of the arable land, or approx. 5 million ha, had to be set aside. The agricultural profession pushed for renewable resources to be grown on this land. With its Green Paper for a Community strategy (COM (96) 576 final), the European Commission laid the foundation for a widespread development for the use of renewable energy, including biofuels. However, it was only France and Germany that used this support framework in the beginning to be able to cultivate renewable resources on land that was set aside. Around 1.0 million ha were set aside in Germany alone at that time. It quickly emerged that rapeseed was by far the principal culture among the renewable

\footnotetext{
"Contribution to the Topical Issue "Biodiesel / Biodiesel"

*Correspondence: d. bockey@ufop.de
}

resources that had the necessary value added potential. It may have ultimately been trivial that processing it into rapeseed oil and meal produced a liquid energy source, which has approximately the same energy density and thus transport value as diesel, and that a valuable protein fodder source is produced at the same time in rapeseed meal. This "valueadded combination" and the fact that the esterification of vegetable (rapeseed) oil proved to be most cost-effective method by far to obtain an alternative fuel for diesel from the very beginning to today were crucial not just for developing a market in the EU, but worldwide. A standardised fuel (today by EN 14214) was produced with practically one process step, while at the same time high-grade pharma glycerine was created, which gradually forced other sources of glycerine out of the market.

Because of the Blair House Agreement reached in 1992 with the USA and the unilateral import-dependence associated with it (Argentina and Brazil still played a subordinate role on the world market for soybeans at this time), the European Farmers' and Cooperatives' Association (COPA-COGECA) called for a protein plan for Europe. Around 25 years later, the use of biodiesel and the co-product rapeseed meal has reached a significance and dimension which could not have even been imagined at that time. 


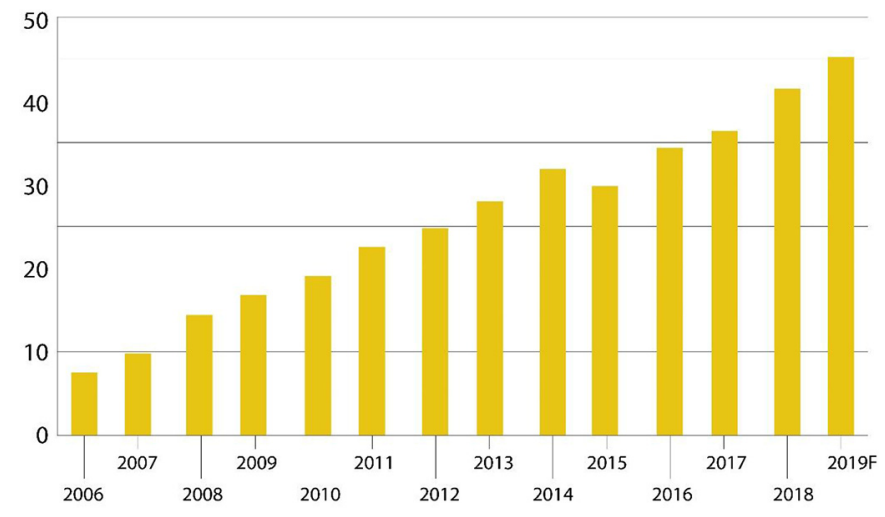

Fig. 1. World prodcution of biodiesel (Mn T). Source: Oil World.

\section{Biodiesel production today - A review}

Global biodiesel production is approx. 35 to 45 million tonnes today, with the absolute number varying depending on the source (F. O. Licht).

The Figure 1 shows the fundamentally rapid development of biodiesel production over the last $10-15$ years. The absolute numbers must not be overestimated with regard to its importance to the global supply. In absolute terms, the biodiesel share in the global diesel supply is comparatively low. In the European Union alone, diesel consumption is around 210 million tonnes. The importance of biofuel, including with regard to the discussion around decarbonising transport and contributing to the fulfilment of the Paris climate change objectives, is rather to do with it being available today for the purpose of beginning gradual decarbonising of fuels. Biodiesel could alternatively be used as a clean fuel specifically in vehicle fleets in sectors, such as heavy-duty traffic or construction and agriculture, where electrification is less realistic in the medium term.

Biofuel from cultivated biomass is the only available alternative to fossil fuels regionally and by extension in the countries of production in the EU 25 that are important today, but also in North and South America and in Asia (Indonesia, Malaysia, Thailand and beginning in China and India). Biofuel contributes to a reduction of the import of crude oil and thus towards improving the external trade balance. But for biofuel made from cultivated biomass (!) especially, critical discussions emerged regarding sustainability, greenhouse gas reduction efficiency and importance for agriculture, associated with the keywords: land-use changes, land usage and the food vs. fuel discussion. Biofuel has been part of the public discussion and critically advanced by environmental associations for a long time now. The politics are therefore, especially in the European Union, on the defensive, rather than about properly exploiting biofuel's sustainably usable potential.

Yet, biodiesel production and market development began in France and Germany with completely different approaches. France managed to introduce a mandatory biofuel addition of approx. 5\% to diesel fuel from the very beginning. At that time, the Union for the Promotion of Oilseeds and Protein Plants (Union zur Förderung von Oel- und Proteinpflanzen-UFOP) decided to promote the market introduction of biodiesel as a clean fuel (B100) through public petrol stations that did not belong to large petroleum companies. What was crucial in UFOP's decision was the very low level of the producer prices at the time, because the market distinguished between "food rapeseed" and "non-food rapeseed" in terms of its price. Luckily UFOP managed to quickly solve the "chicken-egg problem" when Volkswagen AG, on the insistence of the Deutscher Bauernverband (German farmer's union-DBV) and UFOP, offered to retrofit certain end-of-life vehicles to operate on biodiesel and granted a biodiesel release for all new vehicles (VW, Škoda, Seat, Audi) from the model year 1995. Biodiesel had arrived on the market as a clean fuel and was offered at around 1900 public petrol stations in 2007. Biodiesel became attractive for end consumers as a consequence of the price advantage over diesel fuel and thus also became a "product" for public critical perception. Promoting biodiesel made from rapeseed oil on the basis of a tax concession at the time was challenged as early as 1993 with the publication of the first study by the Umweltbundesamt (German Federal Environment Agency-UBA) for a life cycle assessment of rapeseed oil methylester. The life cycle assessment was, and as of this year is, a prominent subject for continuation on the market, firstly for the German and ultimately for the European biofuel industry with the Renewable Energy Directive (2009/ 28/EC - RED I) and the stricter following regulation (2018/ 2001/EC-RED II). These directives introduced biomass resource-specific requirements for such things as greenhouse gas reduction for the whole product chain, from cultivation to transport and biofuel manufacture, as well as the dated crop origin with a key date regulation. This means biomass resources with the intended purpose of producing biofuel in the EU must come from land that was already cultivated before January 2008. This date led to the land being inventoried, a process which is supported with satellite technology today. The head of the Brazilian space agency felt the effects of this in the form of his dismissal at the beginning of August 2019, when he published the latest satellite images of newly cleared woodland.

Germany promoted the market introduction of biodiesel with full tax exemption from 2004 onwards (national implementation of the energy tax directive 2003/30/EC), while at the same time fossil diesel prices had risen since 2000 . The marketing of biodiesel as a pure fuel (B100) increased steadily and in Germany a total volume of approx. 3.2 million tonnes of biodiesel and 0.7 million tonnes of rapeseed oil fuel was achieved in 2007. That corresponded to around a $13 \%$ market share, as measured against the total diesel fuel consumption. The legal basis was the changed Energy Tax Directive, which budgets for this authorisation for the member states to this day, however on the condition of an overcompensation examination. The tax concession led to significant bandwagon effects. There was even an operator for heavy duty vehicle fleets, which produced its own needed biodiesel. The overcompensation examination of the German Federal Ministry of Finance led to a gradual reduction in the tax concession. Since 2013, biodiesel has been fully taxed and a quota system on an energy basis and, as of 2015, the greenhouse gas reduction obligation - the GHG quota - have been introduced as compensation and as security for the asset investments made (protection of legitimate expectation). 
Table 1. EU 28-Biodiesel \& renewable diesel (HVO) production capacity (million litres).

\begin{tabular}{lrrrrrr}
\hline Calendar year & 2012 & 2013 & 2014 & 2015 & 2016 & 2017 \\
\hline Number of biodiesel plants & 264 & 245 & 220 & 201 & 196 & 188 \\
Nameplate capacity & 25494 & 25024 & 22634 & 21928 & 21445 & 20289 \\
Capacity use (\%) & 41 & 42 & 52 & 55 & 55 & 62 \\
Number of HVO-plants & 4 & 5 & 10 & 11 & 188 \\
Nameplate capacity & 1694 & 1828 & 2831 & 3395 & 3395 & 35 \\
Capacity use (\%) & 57 & 88 & 82 & 73 & 77 & 85 \\
\hline
\end{tabular}

Source: GAIN Report Number: NL9022 (05/2019).

Biodiesel is added up to $7 \%$ Vol. as per the European quality standard for diesel fuels (EN 590). The depicted sales promotion of biodiesel on the basis of a tax concession remained a one-off case on this scale from an international perspective.

Globally biodiesel generally gained acceptance as an admixture component in the countries where the corresponding resource production also takes place (USA, Argentina, Brazil, EU, Indonesia and Malaysia). Along with the comparatively procedure cost-effective transesterification of vegetable oil into methyl ester (FAME), the share of hydrotreated vegetable oil (HVO) has gradually increased since the beginning of 2000. Table 1 shows what has been the very complex development of European biodiesel and HVO production.

While the number of facilities for biodiesel production in the EU 28 fell from 264 in 2012 to 188 in 2017 and the production capacity fell with it from around 25 million $t$ to just over 21 million $\mathrm{t}$, the number of production facilities for $\mathrm{HVO}$ increased from four to twelve. The average capacity of 0.28 million $t$ is remarkable. The average production capacity for biodiesel is only 0.11 million tonnes. It should be noted, however, that in the 1990s many small plants with a capacity of less than 0.1 million tonnes were built, which have since ceased production. In principle, it is problematic that reliable statistics do not exist. While the utilisation of the production capacity for biodiesel has been successfully kept at a level of around $55 \%$ with a reduced overall capacity, the utilisation level for HVO facilities is at around $80 \%$ at increased capacity (2015-2018). Small facilities and facilities with poor infrastructure connections in particular have abandoned biodiesel production. As in the EU 28, Groupe Avril owned by the French oilseed farmers stands as a major biodiesel producer, globally international agribusinesses such as B. CARGILL, ADM, Louis Dreyfus, Bunge, Glencore now also set the market development in the biodiesel business. The operational integration and the accompanying locational advantages determine their competitiveness.

\section{Biodiesel turnover and cultivated land development}

The success story of the turnover development of biodiesel made from rapeseed oil began in 2003 with the directive $(2003 / 30 / E C)$ for the promotion of the use of biofuel and with the stipulation of a nevertheless voluntary goal for the member states of a proportion of renewable energy in the fuel market of $5.75 \%$ by $31 / 12 / 2010$ The Energy Tax Directive (2003/96/EC), which also entered into force in 2003, authorised member states to exempt biofuel from taxation under the condition of a compensation examination. This authorisation was implemented by Germany without volume restrictions with the result of the aforementioned almost rapid sales development with the highest turnover in 2007. The introduction of voluntary targets did not however have the result hoped for by the policy. The Renewable Energy Directive (2008/28/ECRED I) initially introduced a binding target for each member state of at least a $10 \%$ share of renewable energy in the transport sector and increased it with the succession directive (2018/2001/EC - RED II) to $14 \%$ in 2030 . These directives and mandatory targets in turn led to national statutory regulations (see Biofuel Mandates in UFOP-Report 2017/18) on the admixture of biodiesel. In the European Union, this had the effect of the German and French biodiesel market no longer setting development, but the European diesel market (EU 28) being the market with by far the highest turnover for biodiesel made from rapeseed oil from 2009 to today. The production of biodiesel increases up to more than 13 million t (Tab. 2).

Table 3 shows the proportion of rapeseed oil in the resource quantity for the European biodiesel production and uses that to calculate an estimate for the cultivated area required based on an EU-wide average yield of $1.3 \mathrm{t}$ of rapeseed oil (approx. 3.25 $\mathrm{t}$ of rapeseed) per hectare. The significance of the biodiesel market is made particularly clear compared with the total cultivated area. The extraordinarily positive development of the biodiesel market was sustained by the development of land for rapeseed cultivation in the member states. Here, the positive producer price trend was the driver behind exploiting the rapeseed cultivation in some cultivation regions on a farm-by-farm basis up to the limit of crop rotation, associated with the problems in plant protection that are known today (see IRC 2019, Berlin). This ultimately increased the overall production in the European Union to around 21 million $t$ of rapeseed. The development of the biodiesel market not only resulted in the build-up of production capacities for biodiesel production, but also for rapeseed preparation. Thus, billions of euros were invested in the member states, in Germany particularly in the former East German states, and in Eastern Europe in expansion and in new oil mills, including the appropriate biodiesel production capacity at some locations. In 2004, barely 5 million $\mathrm{t}$ of rapeseed were processed in 
Table 2. Biodiesel production EU $28(\mathrm{mln} \mathrm{t})$.

\begin{tabular}{|c|c|c|c|c|c|c|c|c|}
\hline & 2007 & 2012 & 2013 & 2014 & 2015 & 2016 & 2017 & 2018 \\
\hline Germany & 2.9 & 2.7 & 2.8 & 3.1 & 3.0 & 3.1 & 3.2 & 3.1 \\
\hline Italy & 0.5 & 0.5 & 0.6 & 1.0 & 1.0 & 1.0 & 1.1 & 1.1 \\
\hline Spain & 0.2 & 0.5 & 0.7 & 1.3 & 1.3 & 1.6 & 2.1 & 2.2 \\
\hline Poland & 0.2 & 0.5 & 0.6 & 0.6 & 0.6 & 0.7 & 0.8 & 0.8 \\
\hline Portugal & 0.1 & 0.3 & 0.3 & 0.3 & 0.3 & 0.3 & 0.3 & 0.3 \\
\hline Austria & 0.3 & 0.4 & 0.4 & 0.4 & 0.4 & 0.3 & 0.4 & 0.4 \\
\hline Czeck Republic & & 02 & 0.2 & 0.2 & 0.2 & 0.3 & 0.3 & 0.3 \\
\hline Netherlands & 0.9 & 0.8 & 1.1 & 1.4 & 1.3 & 1.2 & 1.3 & 1.3 \\
\hline
\end{tabular}

Source: Oil World.

Table 3. Rapeseed oil as feedstock for biodiesel/ha equivalent (1000 MT/ha).

\begin{tabular}{lllllll}
\hline Calendar year & 2012 & 2013 & 2014 & 2015 & 2016 & 2017 \\
\hline Rapeseed oil & 6500 & 5710 & 6200 & 6400 & 6060 & 6300 \\
ha equiv. $^{\text {a }}$ & 5000 & 4400 & 4770 & 4900 & 4660 & 4850 \\
Total area/ha & 6209 & 6714 & 6714 & 6467 & 6535 & 6749 \\
\hline
\end{tabular}

Source: EU Commission/AMI.

${ }^{\mathrm{a}} 1.3 \mathrm{t}$ rapeseed oil/ha (D. Bockey, UFOP).

Germany, but today it is almost 10 million t. However, by implication this also means that in years with low yield results (2018 and 2019) corresponding amounts of rapeseed have to be imported for the purpose of using the oil mills' full capacity. For this reason, European biofuel demand also resulted in the expansion of the rapeseed cultivation in particular in Eastern Europe, for example in Ukraine.

However, the market incentive that came from the European regulation to promote biofuel did not fail to have undesired effects internationally either. Until 2008 imports of soya methyl ester from the USA were increasing considerably. As a result of anti-subsidy proceedings, imports were practically blocked (Fig. 2).

The reason for this procedure was the "use" of the tax concession for soya methyl ester (SME) in the USA as an incentive for financing exports. As that procedure was settled in favour of the European biodiesel industry, two new export nations, Indonesia and Argentina, took over this "gap". As a result of the sharp increase in biodiesel imports from these countries, the European Biodiesel Board (EBB) also successfully introduced anti-subsidy proceedings against these countries. It was possible to practically suspend imports from these countries by 2018. Both countries successfully appealed to the World Trade Organisation (WTO) against the punitive tariffs imposed by the EU Commission in 2017. These revision proceedings had the result that Argentina can export 1.2 million $t$ of SME to the European Union duty-free, while the proceedings are not yet concluded for Indonesia. In July 2019 , temporary punitive tariffs were imposed on a companyspecific basis, ranging from 8 to $18 \%$. The concern is that a similar regulation will be created to find a compromise for Indonesia as was created in Argentina's case, meaning that imports will rise sharply again in future (Fig. 3).

In the case of Argentina, what was clearly decisive was the conclusion of the free trade agreement with the Mercosur countries negotiated by European Commission at the same time. In the case of Indonesia, the proceedings for a free trade agreement with the members of the ASEAN group, beginning in the launch phase, will provide a similar impulse to negotiate. Malaysia would then also join in with this. The European Union is on the defensive here from a negotiation policy perspective, because the initiative for this free trade agreement comes from the EU. This means that biodiesel, like beef or soybeans, has become part of the negotiations around international free trade. The WTO is thus made a passive co-creator and only serves to decide whether to allow adversary proceedings.

However, the competitive pressure on the oilseed markets is not only determined by imports of biodiesel from third-party states, but also by raw material imports for the manufacture of biodiesel in the European Union. The focus of the public and political criticism was and still is on palm oil. As part of the RED II, the EU Council and EU Parliament have agreed on the process for biofuel from palm oil to be discontinued by 2030 , 


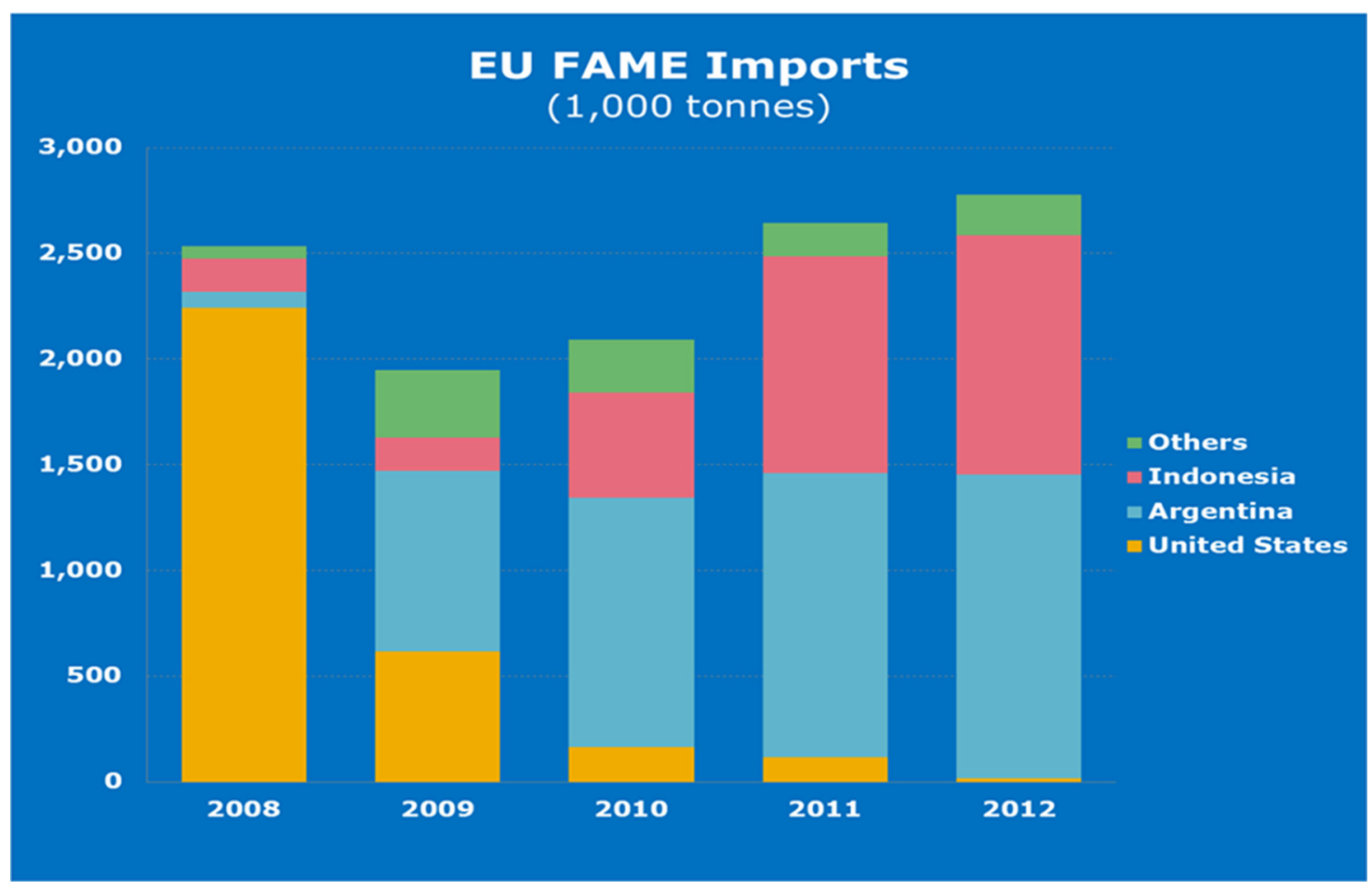

Fig. 2. Import of biodiesel 2008-2012 (MT). Source: FO Licht.

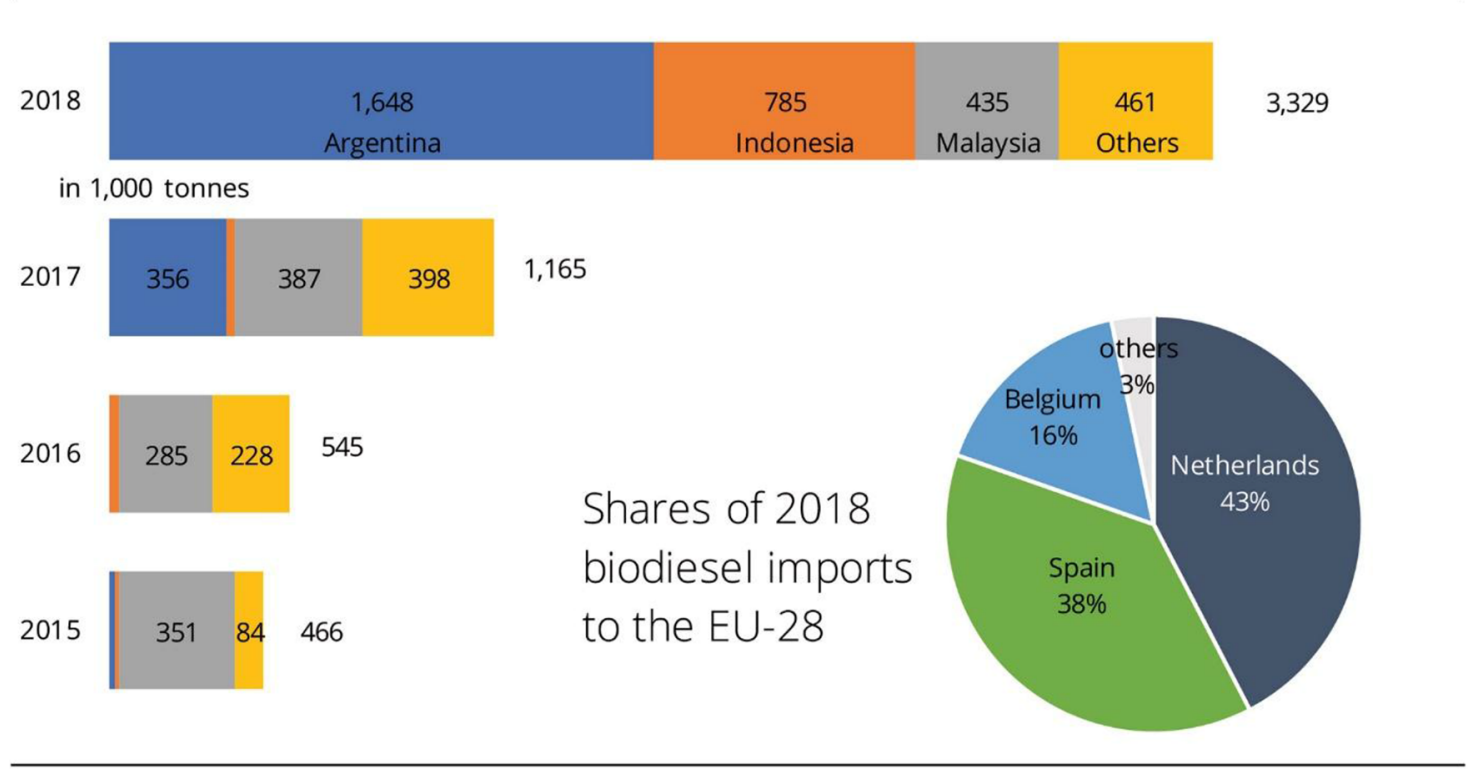

Fig. 3. Imports of biodiesel 2018. Source: Eurostat, AMI.

however the concern is that this will be subverted by a bilateral agreement, as was previously conducted. The market situation for vegetable oil and biodiesel is critical in the European Union and internationally, because of the constantly growing production of, in particular, palm oil. At over 200 million $t$ in annual production, vegetable oil production has reached a new volume level, as have the price intervals between the most important vegetable oils (Fig. 4).
The excess volumes depress markets and prices with the consequence that the proportion of palm oil for creating biodiesel in the European Union (see Tab. 4) has increased from around 1.5 million $\mathrm{t}$ in 2012 to 2.6 million $\mathrm{t}$ in 2018 . Including the imports of biodiesel made from palm oil from Indonesia and Malaysia, the total share is around 3.4 million $t$. Exact information regarding the actual amount is not available owing to the absence of a corresponding necessary statistical 


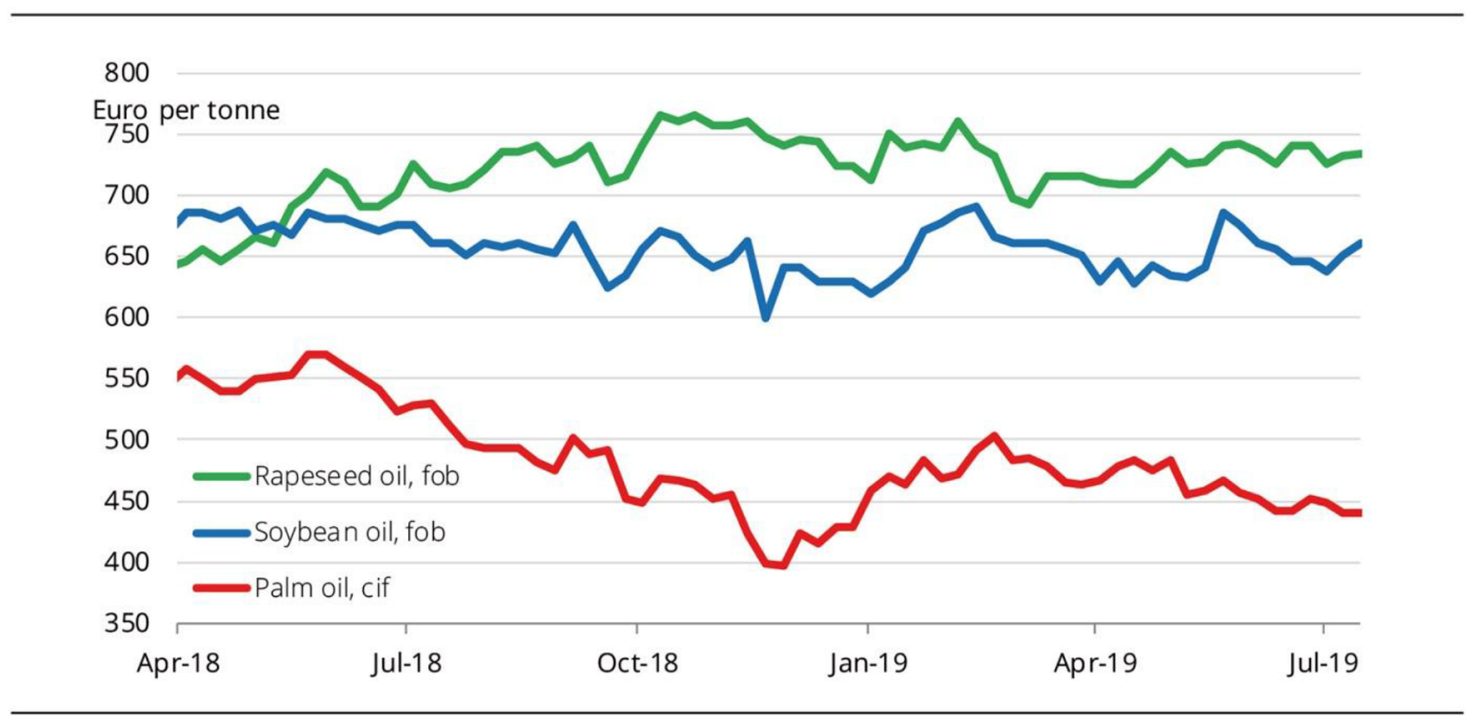

Fig. 4. Wholesale prices of vegetable oils. Source: AMI.

Table 4. Feedstock use for biodiesel + renewable diesel (HVO) (1000 MT).

\begin{tabular}{lrrrrrr}
\hline Calendar year & 2012 & 2013 & 2014 & 2015 & 2016 & 2017 \\
\hline Rapeseed oil & 6500 & 5710 & 6200 & 6400 & 6060 & 6300 \\
UCO & 800 & 1150 & 1890 & 2400 & 2620 & 2770 \\
Palm oil & 1535 & 2340 & 2240 & 2340 & 2315 & 2650 \\
Soybean oil & 720 & 870 & 840 & 540 & 610 & 930 \\
Animal fats & 360 & 420 & 920 & 1030 & 795 & 795 \\
Sunflower oil & 300 & 290 & 310 & 210 & 250 & 180 \\
Other, pine/tall oils, fatty acids & 220 & 335 & 370 & 560 & 615 & 635 \\
Biodiesel + HVO, on-road use & 14508 & 13053 & 14461 & 14189 & 14127 & 15600 \\
\hline
\end{tabular}

Source: GAIN Report Number: NL9022 (05/2019).

record by the EU Commission or by the EU member states. Thus, the data regarding the total amount of biofuel made from palm oil (biodiesel/HVO) vary between 2.5 and 3.4 million $t$.

\section{Driving factors for international biodiesel production}

One of the most important factors for biodiesel production in North and South America is the constantly increasing global demand for soybean meal for animal feed and with it the increasing price of soybean meal. The price of soybean meal thus sets the price for soybeans and ultimately the extent of cultivation in addition. Soya oil production is increasing much faster than the food market (edible oil) can absorb as a result of the similar increase in the size of harvests. The only other outlet is the biodiesel market. That is why first the USA (although used cooking oil and animal fat additionally play an important role today), then Brazil and Argentina, introduced quota systems for admixture in diesel fuel that are much higher than the admixture quotas in the EU (Tab. 5).

The Argentinian diesel market is not sufficiently absorptive in contrast to the diesel market in Brazil, although Argentina's
Table 5. Biodiesel-admixture mandates higher outside of EU.

\begin{tabular}{lll}
\hline Biofuel mandates $(\%)$ & 2018 & 2019 \\
\hline Indonesia & 20 & $20(30)$ \\
Malaysia & (CHP: 30\%) & (CHP: 30\%) \\
Argentina & $5 / 7$ & 10 \\
Brazil & 8 & 12 \\
Thailand & 7 & 11 \\
USA & 7 & 10 \\
RFS programme & 5.8 million t & 6.3 million t \\
\hline
\end{tabular}

Source: FO Licht, biofuel digest, FAS, Platts.

admixture quota is $10 \%$. The soya complex, including the biodiesel industry, is also of extraordinarily great economic importance to Argentina. The country is dependent on agricultural exports-including biodiesel. A similar assessment also applies to Indonesia. The palm oil sector is also an important element for the national economy and is of great importance for protecting and creating jobs. While the biofuel policy in the European Union and its future along with the 


\section{Evaporated proportion / vol \%}

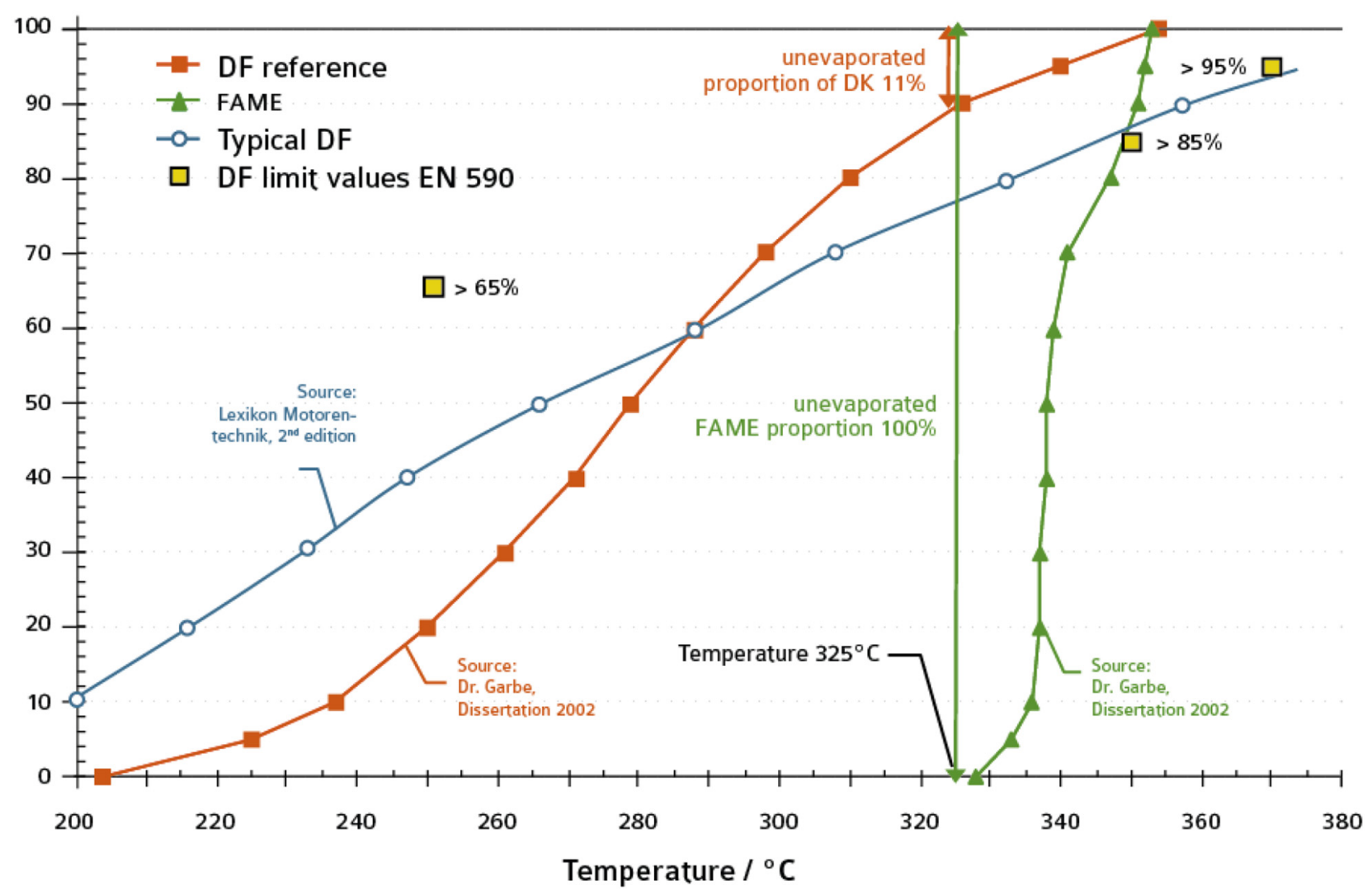

Fig. 5. Evaporation behaviour diesel/biodiesel. Source: UFOP position paper "Action areas and the need for research in biofuels".

"food vs. fuel debate" are primarily focused on environmental policy against the backdrop of meeting the targets of the Paris Climate Change Agreement, the motivation in the USA, Brazil, Argentina, Malaysia and Indonesia is more about market policy in the interests of supporting producer prices as well as about reducing the dependence on imported fossil fuel.

The Paris Climate Change Agreement states that the signatory states must submit a national climate and energy plan by 2020 as a contribution towards fulfilling its goal of a $1.5^{\circ} \mathrm{C}$ increase in global temperatures compared to pre-industrial levels. The agricultural export countries will therefore credit themselves with their "biofuel policy". The next conflict is therefore foreseeable, since not just environmental groups reject biofuel made from cultivated biomass. This assessment must be emphasised against this backdrop, because companies in the European oil industry, but particularly European car manufacturers, are signalling that biofuel from cultivated biomass is not a viable option for the future. Instead they support policies covering biofuel from residue and waste materials and the introduction to the market of so-called synthetic fuels from renewable power.

\section{Engine and fuel chemistry-related challenges}

The automotive industry's restraint is however also justified as regards the matter of how the various challenges of fuel stability and the constantly increasing statutory emissions requirements can be fulfilled with an "oxygenate" such as vegetable oil methyl ester (FAME) as a fuel alternative. Biodiesel does not have the best "reputation" from a chemistry perspective. Biofuels that do not cause interaction effects (with other fuel components, with seal materials, residue effects and biological growth, etc.) are preferred. That is why HVO or direct co-processing of vegetable oil in the oil refinery is preferred. The fundamental problem is the poor boiling characteristics of biodiesel compared to diesel fuel. This necessitates measures to adapt the engine, particularly when the admixture share is increased to e.g. $30 \%$. This crucial behaviour could be improved by rapeseed varieties with fatty acids of C-12. But not yet any attempts had been undertaken to proof this option (Fig. 5).

Against the backdrop of the depicted global developments, an important intersection still has to be addressed in the issue of the required proactive fuel system research. This is owing to the fact that engines and exhaust after treatment are undergoing further developments not only in the European Union, also in in the USA, South America and Asia in quality even in these countries, because the statutory emissions requirements are also constantly increasing here. European engine manufacturers and vehicle suppliers are often the same companies in the EU and in third party states. Consequently, the biofuel policy in these countries forces vehicle manufacturers to supervise the market introduction of fuels with a higher proportion of biofuel. Germany is leading the research in 
biodiesel and HVO fuels. Many projects and their results, promoted by state sponsors (e.g. FNR, AIF) and economic funding agencies (e.g. FVV, UFOP), as well as even commercial enterprises, are the basis for a corresponding transfer of knowledge and/or exchange with experts from the worlds of business and research in these countries. Against this backdrop, it is an existential issue for the biodiesel industry to support the research associations and networks that exist today and above all to bring young academic talent into this field of research. That is because this is likewise an important signal that the combustion engine has a future internationally in principle. This also means that the international exchange of research results must also be promoted in a targeted manner, one particular aspect where there is need for action. UFOP is the co-host and organiser of the annual conference named the "International Conference on Renewable Mobility-Fuels of the Future" (https://www.fuels-of-the-future.com/). Here, the results of the projects promoted by UFOP as well as other institutes (bioethanol, biogas, synthetic fuels-innovative production methods) are presented, which co-determine the perspective of biodiesel - including rapeseed oil for manufacture.

\section{Further reading}

Biofuel mandates in: Biodiesel 2017/2018 Report on Progress and Future Prospects - Excerpt from the UFOP Annual Report, pp. 39-41. Available from https://www.ufop.de/files/5315/3994/5756/WEB_U FOP_1605_Biodieselauszug_EN_191018.pdf.
Council Directive 2003/96/EC of 27 October 2003 restructuring the Community framework for the taxation of energy products and electricity. Available from https://eur-lex.europa.eu/legal-content/ $\mathrm{EN} / \mathrm{TXT} / \mathrm{PDF} /$ ?uri=CELEX:320q03L0096\&from=DE.

Directive 2003/30/EC of the European Parliament and of the Council of 8 May 2003 on the promotion of the use of biofuels or other renewable fuels for transport. Available from https://eur-lex.europa. eu/legal-content/EN/TXT/PDF/?uri=CELEX:32003L0030\&from= EN.

Directive (EU) 2018/2001 of the European Parliament and of the Council of 11 December 2018 on the promotion of the use of energy from renewable sources. Available from https://eur-lex.europa.eu/ legal-content/EN/TXT/?uri=uriserv:OJ.L_.2018.328.01.0082.01. ENG.

Green Paper for a Community strategy (COM (96) 576 final). Available from http://aei.pitt.edu/1280/1/renewalbe_energy_gp_ COM_96_576.pdf.

The Renewable Energy Directive (2009/28/EC-RED). Available from https://eur-lex.europa.eu/LexUriServ/LexUriServ.do?uri=OJ: L:2009:140:0016:0062:en:PDF.

GAIN Report Number: NL9022. Available from http://agriexchange. apeda.gov.in/marketreport/Reports/Biofuels_Annual_The_Ha gue_EU-28_7-15-2019.pdf.

UFOP information service - "Biofuel statistics - Graph of the Week". Available from https://www.ufop.de/english/news/chart-week/.

UFOP-Expert Commission "Biofuels and renewable resources" and projects, pp. 22-25. Available from https://www.ufop.de/files/5315/ 3994/5756/WEB_UFOP_1605_Biodieselauszug_EN_191018.pdf. UFOP position paper "Ḧandlungsfelder und Forschungsbedarf bei Biokraftstoffen" ("Action areas and the need for research in biofuels"). Available from https://www.ufop.de.

Cite this article as: Bockey D. 2019. The significance and perspective of biodiesel production - A European and global view. OCL 26: 40. 